\title{
Psychological and pedagogical conditions for the formation of value-semantic sphere of students of technical specialties
}

\author{
Oksana Nikolenko $^{1}$, Lyudmila Zheldochenko ${ }^{2}$, Natalia Lomova ${ }^{1, *}$ \\ ${ }^{1}$ Don State Technical University, 1, Gagarina Sq., 344003, Rostov-on-Don, Russia \\ ${ }^{2}$ Southern Federal University, 105/42, Bolshaya Sadovaya str., 344006, Rostov-on-Don, Russia
}

\begin{abstract}
The article considers the psychological and pedagogical conditions necessary for the formation of the value-semantic sphere of students technical specialties. The article is devoted to the theoretical aspects of the value-semantic approach in modern education. The problem is considered through the prism of concepts that consider the valuesemantic sphere, the problem of meaning, factors and conditions that affect the process of forming meaning-life and value orientations in youth. The degree of formation of the value-semantic sphere affects the quality of life, self-determination, and overall satisfaction with life. Various approaches to the formation of meaning-life and value orientations are considered.
\end{abstract}

\section{Introduction}

The current state of the problem under consideration makes it necessary to analyze the psychological and pedagogical conditions that are important for the formation of the valuesemantic sphere of students. The relevance of this study is due to the fact that the meaning of life and values determine the way of life, self-determination of a person and its potential in the present and future. Not only the existence of an individual, but also of society as a whole depends on these guidelines [1].

The period of the most intensive formation of the value-semantic sphere falls on youth, the period of student life. The main approaches to the study of the value-semantic sphere of personality in modern psychology are activity-based, integrative, personal-meaning, existential-humanistic,interactionist, social-psychological approaches, the concept of D. Uznadze's installation.

\section{Research materials and methods}

The value-semantic sphere was studied By V. Frankl, L. S. Vygotsky, A. G. Asmolov, A. N. Leontiev, D. A. Leontiev, A. A. Bodalev, I. V. Abakumova, V. E. Chudinovskiyb. S. Bratus, F. E. Vasilyuk, S. L. Rubinstein, M. Rokich, D. Uznadze, and others. Different psychological schools bring their own understanding of meaning and value. But they agree

\footnotetext{
*Corresponding author: lomovanatalia@mail.ru
} 
that value orientations determine the behavior of an individual and are part of the personality structure. If a person accepts certain values of society, then he considers these values as part of his personal system and follows them. Meaning as a vital reference point of a person, as the main life value, is considered in the scientific works of A. A. Bodalev, who says that the meaning of life is the greatest and most significant value in human life[2 p. 29-332 Bodalev A. A. Perception and understanding of a person by a person.

V. Frankl understood the values of the individual as meaning inherent in the majority of members of society, the whole of humanity during its historical development, experiencing certain values, a person acquires the meaning of life (V. Frankl, 1997).

M. Rokich divided the values of the individual according to their functional meaning into two main groups: terminal and instrumental, acting, respectively, as personal goals and means of achieving them (M. Rokich, 1973)[2]. But. Maslow subdivided values depending on the focus on personal development or on the preservation of homeostasis, into higher (development values, existential values) and regressive (conservation values) [3].At the same time, terminal and instrumental, higher and regressive, internal and external values may correspond to different levels or stages of personal development.

The period of the most intensive formation of the system of value-semantic orientations and increased susceptibility is the youth age, most of the boys and girls are students of educational institutions. In adolescence, a person is tasked with making a decision an important decision - the choice of a profession. In a situation of life choice, a person is guided by those values that he considers the most important, relevant and personally important. Society has a huge influence on the formation of values .

N. Howe and W. Strauss consider the values of modern youth from the perspective of generations. Modern youth belongs to the "generation $\mathrm{Y}$ and $\mathrm{Z}$ ". "Generation $\mathrm{Y}$ " is born in the period from 1984 to 2000 , "Generation $Z$ " in the period from 2000 to 2020 .. A child of 12-14 years old is already forming generational deep values. During this period, the child does not yet realize the importance of what is happening to him, can not critically evaluate some events in his life, the life of his family, as well as the life of society and the country. This formation is influenced by social events (social, political, economic, etc.), and the role of family education and educational institutions is great. There are a lot of predictions about generation Z, but not much information yet. Generation Y "Network generation" is more studied. Mobile phones and the Internet are their usual reality. Many representatives simply "live in the network", work through the Network, communicate, and have fun. The value system of this group includes such concepts as responsibility, civic duty, and morality. The negative manifestations include the ability and desire to obey, not critical thinking, superficiality of judgments, they strive to know about everything a little bit, without delving into the essence, which makes it possible to manipulate them. This generation is more susceptible to negative influence from the outside, terrorist and extremist views (high level of participation in riots), as they are aimed at a quick result, do not delve deeply into the essence of the problem, and are not used to being responsible. For them, it is important and valuable: the opportunity to make a choice, personal independence, internal comfort. The desire for a healthy lifestyle is a distinctive feature of this generation[4].

The formation and development of the semantic sphere of youth is influenced by Hobbies, professional self- determination and choice of friends, education, environment and socio-economic factors, while at the same time searching for the answer "what is the meaning of my life?", also affects the life of a young person. It is also necessary to take into account the role of youth organizations in the development of humanistic value orientations of students of higher educational institutions [5]. Slotina T. V. points out that the basis of the concept of meaning in life are the values and needs that make up the basis of the individual. The meaning-in-life concept includes a generalized understanding of the goal, process, and result of one's life. 
A. G. Asmolov considers personal meaning as a consequence of interiorization and reflection in the mind of the entire spectrum of relationships between the individual and the surrounding world, all that happens to the individual. Asmolov calls intrapersonal meaning, expressed as a determination to perform certain actions in a specific way, a"semantic attitude".

I. V. Abakumova, defines meaning as "the relationship between the subject and the object or phenomenon of reality, which is determined by the place of the object (phenomenon) in the life of the subject". Abakumova offers the following definition of a meaning-life strategy a meaning-life strategy is a stable system of personal meanings of an individual formed during ontogenesis on the basis of mental experience, which allows optimizing or minimizing the activity of the subject in relations with objective reality and manifesting itself in relation to the goal, process and result of activity, as well as in relation to life and oneself [6]. I.V. Abakumova developed a conceptual integrated model of meaning formation, which includes the most generalized components and patterns characteristic of all areas of research of meaning. The problem of meaning formation in students during the course of study was studied in the works of A. G. Asmolov ("Semantic pedagogy"), A. Belousova ("Organization of joint thought activity of schoolchildren") $[7,8]$.

In the formation of a person passes through several levels of development of the valuesemantic sphere.B. S. Bratus identifies the following levels of personality development: impersonal, egocentric, group-centered, and prosocial.

V.A. Yadov presents a scheme of transition from lower attitudes to higher value orientations (see table 1). He believes that a person has a hierarchy of needs, which corresponds to a hierarchy of situations, which then passes into a hierarchy of appropriate behavior. Only the highest level of needs associated with self-awareness of belonging to society, culture, forms a person's value orientations and value behavior. Desirable, socially approved value orientations may not be formed independently. Therefore, the psychological and pedagogical problem of identifying and creating conditions for the formation of value orientations is relevant. It is important to determine the indicators and criteria, the indicators that can be used to identify a young person's value orientations that have already been formed [9].

Table 1. A scheme of transition from lower attitudes to higher value orientations.

\begin{tabular}{|c|c|c|c|c|}
\hline Levels & $\begin{array}{c}\text { Hierarchy of } \\
\text { needs }\end{array}$ & $\begin{array}{c}\text { Hierarchy of } \\
\text { situations }\end{array}$ & $\begin{array}{c}\text { Hierarchy of } \\
\text { dispositions }\end{array}$ & $\begin{array}{c}\text { Form of } \\
\text { expression }\end{array}$ \\
\hline & Vital needs & $\begin{array}{l}\text { The subject of the } \\
\text { situation }\end{array}$ & $\begin{array}{l}\text { Fixed } \\
\text { installations }\end{array}$ & Behavioral act \\
\hline & $\begin{array}{l}\text { The need for } \\
\text { communication in } \\
\text { a small group }\end{array}$ & $\begin{array}{l}\text { The situation of } \\
\text { group } \\
\text { communication }\end{array}$ & $\begin{array}{l}\text { Social fixed } \\
\text { installations }\end{array}$ & acts \\
\hline & $\begin{array}{l}\text { The need for } \\
\text { activity in a } \\
\text { particular field of } \\
\text { activity }\end{array}$ & 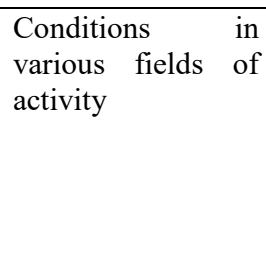 & $\begin{array}{l}\text { General } \\
\text { orientation of } \\
\text { interests in a } \\
\text { specific area of } \\
\text { social activity or } \\
\text { basic social } \\
\text { attitudes }\end{array}$ & behavior \\
\hline & $\begin{array}{l}\text { The need for } \\
\text { inclusion in an } \\
\text { integrated social } \\
\text { system }\end{array}$ & $\begin{array}{lr}\text { General social } \\
\text { conditions of life: } \\
\text { economic and } \\
\text { political features of } \\
\text { lifestyle }\end{array}$ & $\begin{array}{l}\text { Personal value } \\
\text { orientations }\end{array}$ & $\begin{array}{ll}\text { Integrity } & \text { of } \\
\text { behavior } & \text { in } \\
\text { various areas } & \end{array}$ \\
\hline
\end{tabular}


A person may experience a loss of semantic values (an existential vacuum). Speaking about this problem, it can be argued that the lack of meaning creates a state in a person that V. Frankl calls an existential vacuum. An existential vacuum is a widespread phenomenon among young people today. Excess of free time, satisfaction of needs without making an effort, availability of goods, entertainment, not wanting to work, satiety this is not a complete list of what can prevent the formation of the value-semantic sphere.

\section{Results and discussions}

The value-semantic sphere of the individual is formed, transformed and expressed in the process of educational or professional activity. Objective contradictions of modern education they allow us to address the value-semantic approach in education. Effective formation of the value and meaning sphere of students is provided, in our opinion, by the implementation of a number of psychological and pedagogical conditions. According to A. V. Petrovsky and a number of other scientists in psychology, conditions are considered as a set of phenomena of the external and internal environment that probabilistically affect the development of a specific mental phenomenon, and this phenomenon is mediated by the activity of the individual.

In pedagogy, a condition is understood as a set of external circumstances in which educational activities take place, and the circumstances of the life of its subject (P. I. Pidkasisty, etc.) A number of researchers indicate the need to create conditions in the university for the formation of a creative personality [10,11], pedagogical models are developed to implement the moral-ecological function of educating students in a university. Researchers emphasize the importance of art in the formation of environmental and humanistic values of a person, especially among students of technical specialties [12].

One of the psychological and pedagogical conditions that determine the dynamics of the process of forming a system of value-semantic sphere of students is the conditions of educational and professional activity. The structure of educational and professional activity highlights the components of its implementation: personal values of students, values of professional activity and values of the educational space of the University. These values are interdependent and the effectiveness of educational and professional activities depends on the formation of each of these components.

An important role in the formation of psychological and pedagogical conditions is played by the personality of the teacher, the ability to find an approach, to establish contact with students.Students prefer to come into contact, with a teacher who has characteristics such as sincerity, leadership, compassion, restraint, responsibility, kindness, cordiality and others. It is established that among the nonverbal patterns of behavior that contribute to the effectiveness of meaning, pupils are considered "gestures appropriate to the situation communication", "communication distance, which is regulated in accordance with the situation" and "the manifestation of the ability to listen and speak". "In the students' perceptions as the socio-psychological characteristics of a teacher who effectively implements meaning, the following were highlighted. He must responsibly and creatively approach his work, conduct himself restrained, calmly and smartly. Sincerely treat your students. He must have leading qualities and be pleasant in communication. Among the characteristics that do not contribute to the effectiveness of the meaning were the following. Such a teacher is silent and unsure of himself, neglects the rules of the school charter or is completely submissive, he is inconsistent in his statements, doesn't necessarily, dishonestly performs his duties and fulfills them without zeal and attention, emotionally unstable " [13].

"The role of the value-semantic approach in professional education consists of at least two functions. First, creating an image of the future, prospects for personal development. Secondly, the formation and creation of a moral system for evaluating future professional 
activities"[14]. The motivational and procedural component of training also requires revision and rethinking. This applies to existing and new teaching methods and technologies that " fill the educational process with meaning formation and senseknowledge, formed through the system of lived values in the process of interaction with other active subjects.

The set of necessary pedagogical conditions includes: value orientations of teachers, individual work with students, stimulation to search for self-knowledge and selfdetermination, a positive attitude to the formation of a value attitude in students (Uznadze, I. V. Abakumova), the ability to reflect, reliance on the subjective experience of students, providing freedom of choice and interpersonal communication, active inclusion in design activities.

\section{Conclusions}

Thus, the period of the most intensive formation of the system of value-semantic orientations and increased susceptibility is the stages of youth, characterized by the action of all three mechanisms for the formation of the value-semantic sphere of the individual. During this period, the foundations of the future type of activity are laid, and the process of personal and professional self-determination takes place. The period of study at the University can be defined as a special meaning-life period in the life of a person associated with identification with the subject of professional activity. The meaning of life, one of the important worldview concepts that is of great importance for the formation of personal maturity, " which is aimed at self-improvement and self-realization, successful and productive in all spheres of social life, is able to act quickly and effectively in various life situations, adapt to changing living conditions and creatively transform them" [15].The specificity of the student period is that the acquisition of important professional and personal orientations is complicated by the lack of proper experience, instability in views, and inadequate self-esteem. In this regard, it is necessary to create such psychological and pedagogical conditions that would contribute to the process of training at each stage, as professionalization, accumulation of theoretical knowledge, formation of practical skills and abilities, and actualization of personal meanings and values, I form a harmoniously developed personality.. Educational and professional activity promotes self-development, self-realization of students, formation of value attitudes and meaning-based orientations, determines professional self-actualization [16].Psychological and pedagogical conditions should correspond to modern circumstances, should help in the formation of the valuesemantic sphere of students.

\section{References}

1. O.F. Nikolenko, Psychology of learning 5, 58-64 (2018)

2. M. Rokeach, Free press 5, 20-28 (1973)

3. A. Maslow, Toward a Psychology of Being (Wiley, 1998)

4. O.F. Nikolenko, Psychology of learning 9, 72-83 (2017)

5. R.A. Valeeva, L.A. Rybakova, Procedia - Social and Behavioral Sciences 141, 817 821 (2014)

6. L.T. Kagermazova, I.V. Abakumova, Z.V. Masaeva, Psychological problems of the meaning of life and Acme, 137-141 (2019)

7. A.K. Belousova, Psychology of training 9, 4-14 (2015)

8. A.K. Belousova, Self-organization of joint mental activity (R-N-D, RSPU, 2002) 
9. V.A. Yadov, N.V. Yadov, Poisons Sociological Essays (Yearbook, Moscow, 1991)

10. N. Yachina, G. Fahrutdinova, Procedia - Social and Behavioral Sciences 177, 213 216 (2015)

11. I. Zhuravlyova, S. Zhuravlyov, Procedia - Social and Behavioral Sciences 206, 445 454 (2015) doi: 10.1016/j.sbspro.2015.10.081

12. N. Kuprina et al., Procedia - Social and Behavioral Sciences 214, 135 - 142 (2015)

13. A. Korochentseva, E. Suroedova, N. Khachaturyan, O. Nikolenko, SHS Web of Conferences 70, 08020 (2019) https://doi.org/10.1051/shsconf/20197008020

14. N.G. Milovanova, I.G. Pchelintseva, A.V. Chumakova, Pedagogical journal 7(6), 194201 (2017)

15. Ju. Rashupkina, O. Nikolenko, INTED2017. 11th International Technology, Education and Development Conference with Conference proceedings, 6300-6303 (IATED Academy, 2017)

16. L.D. Zheldochenko, O.F. Nikolenko, Economic and humanitarian research of regions 6, 12-16 (2017) 